\section{Por uma escola pública, democrática, reflexiva e plena de conhecimentos}

\author{
Anita Handfas (iD) [0000-0002-3804-7109]
}

Universidade Federal do Rio de Janeiro, Faculdade de Educação, Laboratório de Ensino de Sociologia Florestan Fernandes, Rio de Janeiro, RJ, Brasil <anitahandfas@gmail.com>

FRIGOTTO, Gaudêncio (org.) Escola "sem" Partido - Esfinge que ameaça a educação e a sociedade brasileira. Rio de Janeiro: UERJ, LPP, 2017, 144 p.

Resistência ao autoritarismo; gênese e significado; educação; redes políticas; criminalização do trabalho pedagógico; avanço do irracionalismo; democracia; reestruturação curricular - esses são apenas alguns dos aspectos do proclamado movimento Escola sem Partido, tematizado ao longo da coletânea organizada por Gaudêncio Frigotto. Fruto de investigações minuciosas realizadas por dezenove pesquisadores, seu objetivo é mapear os principais aspectos do Escola sem Partido, cujas primeiras manifestações surgiram em 2004, ganhando fôlego desde então e deixando rastros cada vez mais marcantes no contexto atual de avanço do obscurantismo no Brasil.

O livro é uma obra de compreensão sociológica acerca das conexões entre educação e autoritarismo. A coletânea é composta por nove capítulos. O eixo condutor que atravessa o livro é traçado pelos princípios da escola pública, democrática e laica, em diálogo crítico com os preceitos do Escola sem Partido, como já aponta o subtítulo. Ou seja, nesse livro há um terreno comum por onde percorrem os autores, em defesa de uma escola que promova o conhecimento científico, a reflexão e o debate, princípios a partir dos quais, os capítulos buscam oferecer ao leitor um diagnóstico rigoroso do referido movimento.

Nessa direção, o livro demonstra com clareza de dados e informações que, a despeito da propalada liberdade, o Escola sem Partido constrange o professor, sufoca o trabalho pedagógico e encoraja práticas de denuncismo entre os sujeitos que convivem no espaço escolar.

Para dar conta da diversidade de olhares contemplados na coletânea, o organizador mobilizou um conjunto de temas tratados nos capítulos que lograram, por um lado, focar em características específicas do movimento e, por outro, constituir um todo do fenômeno investigado, elucidando as questões centrais sobre o que vem a ser esse movimento, assim como os impactos sobre a educação, a escola e o trabalho docente.

O livro inicia com uma apresentação de Maria Ciavatta que nos convida à reflexão, mostrando que, ao buscar a gênese do Escola sem Partido, os autores da coletânea chamam à organização e à ação todos aqueles que lutam por uma sociedade democrática e por uma educação emancipadora.

No primeiro capítulo, Gaudêncio Frigotto nos chama a atenção para a ameaça que representa o Escola sem Partido. Ao evocar a metáfora da "esfinge" e do "ovo da serpente", adverte para os perigos da propagação da ideologia desse movimento, cujo alvo é o esvaziamento da função social da escola pública. Abrindo caminho para os capítulos seguintes, Frigotto traça um amplo panorama sobre a gênese do movimento, mostrando que a ideologia tão propalada por ele funciona, em última instância, como um mecanismo para encobrir seus interesses políticos e econômicos, tendo em vista a posição atual ocupada pelo Brasil no interior das contradições do capitalismo.

No capítulo seguinte, é a vez de Fernando Penna analisar o discurso do Escola sem Partido. O autor mostra que por detrás daquilo que muitos professores entendiam por absurdo, deboche e mesmo improvável, o movimento alcançou êxito em suas posições na escola e na sociedade, ao partir de uma estratégia discursiva simples e próxima ao senso comum que desqualifica o professor e coloca pais e responsáveis pelos alunos numa posição inquisidora. $\mathrm{O}$ autor destaca e analisa quatro aspectos do discurso do movimento: (1) a concepção de escolarização; (2) a desqualificação do professor; (3) a acusação da escola como espaço de ideologização, e 
dos docentes como militantes travestidos de professores.

O terceiro capítulo foi escrito por Betty Solano Espinosa e Felipe Campanuci Queiroz. Nele, os autores adotam a perspectiva analítica das redes sociais, para quantificar e qualificar os agentes e as ideias que formam o Escola sem Partido, buscando identificar suas interações com atores de variados espectros sociais. Ao mapear a teia de articulação existente, Bety e Felipe concluem que os membros que compõe o movimento estão vinculados a partidos políticos, instituições religiosas e grupos empresariais poderosos.

No quarto capítulo, Eveline Algebaile traça um quadro geral "do que é", "como age" e "para que serve" o Escola sem Partido. Ao esquadrinhar a plataforma principal do movimento, um sítio virtual da internet, a autora mostra que, ao contrário do que pode parecer, o Escola sem Partido não se constitui enquanto um movimento, no sentido de agir e organizar seus adeptos orgânica e fisicamente, mas tem todas as suas ações veiculadas por meio de uma plataforma virtual, espaço onde são difundidas suas ideias e divulgadas as orientações para denúncias contra supostas práticas de doutrinação ideológica por parte dos professores.

O capítulo seguinte foi escrito por Marise Ramos e se dedica a analisar os impactos das ideias difundidas pelo Escola sem Partido sobre o trabalho pedagógico dos professores. Para tal, a autora desmonta a suposta neutralidade do ato educativo aventada pelo movimento, asseverando que as contradições e disputas por concepções de mundo presentes no espaço escolar nada mais são do que manifestações salutares inerentes ao ato de educar. Para a autora, sem isso, a escola se torna amorfa e cativa da ideologia das classes dominantes.

O sexto capítulo, escrito por Mattos et al, lembra que o debate em torno do caráter secular e democrático da educação pública vem de longa data e a atuação de grupos religiosos contra a laicidade é uma marca na história da educação brasileira. Na atualidade, segundo os autores, essas posições se revestem em ataques aos conteúdos veiculados na escola e nos livros didáticos, sob o pretexto do Escola sem Partido, de que somente aos responsáveis dos alunos caberia velar pelos valores morais, religiosos e sexuais de seus filhos.

Em seguida, o capítulo de Isabel Santa Barbara, Fabiana Lopes da Cunha e Pedro Paulo Gastalho de Bicalho parte do entendimento de que historicamente a escola tem sido uma instituição normalizadora e disciplinadora da classe trabalhadora. No entanto, os autores argumentam que quando a escola passa a representar uma oportunidade real de ascensão social das camadas populares, setores conservadores interessados em preservar a hierarquia social e os valores das classes dominantes passam a atacar a escola e os professores. É neste cenário que o Escola sem Partido ganha terreno para operar por meio de mecanismos de "governamento", no sentido de impor novas condutas e subjetividades no espaço escolar.

O oitavo capítulo, escrito por Rafael de Freitas e Souza e Tiago de Oliveira propõe uma reflexão filosófica sobre o Escola sem Partido. Partindo dos conceitos de doxa (opinião ou crença comum) e logos (razão), os autores mostram como o obscurantismo que atravessa o discurso do movimento fere os princípios da razão e do conhecimento científico na escola, garantidos inclusive pela legislação nacional, para dar lugar à opinião, ao senso comum, fortalecendo assim as crenças e convicções religiosas, como mais uma forma de atacar o conhecimento e o trabalho pedagógico realizado de forma competente pelo professor.

Fechando a coletânea, o capítulo de Paulino José Orso é propositivo de uma alternativa pedagógica e curricular que possa fazer frente ao desmonte da escola, do conhecimento e do trabalho pedagógico do professor. Nessa direção, o autor defende um currículo que contemple uma sólida formação teórica, possibilitando ao aluno uma visão crítica sobre o passado histórico e a compreensão da sociedade atual. Com a apresentação sintética dos capítulos que compõe a coletânea Escola "sem" Partido - Esfinge que ameaça a educação e a sociedade brasileira, fica claro que se trata de um livro da maior importância, sobretudo no contexto atual de avanço do obscurantismo do governo Bolsonaro que ataca a ciência e o conhecimento 
científico porque quer supor que tudo não passa de construções. A ideologia do Escola sem Partido quer fazer crer que a opinião é tão importante quanto o conhecimento, visão que nos empurra para o relativismo, tão contrário ao esforço investigativo e ao conhecimento, tão necessários para a construção de uma escola libertária. Em tempos sombrios como os que estamos enfrentando atualmente, parece ser mais uma vez oportuna a advertência feita por Saviani (2018) de que a luta pela escola democrática passa por sua articulação com a luta pela democratização da sociedade.
Nesse sentido, a coletânea em pauta é a um só tempo, um livro de denúncia e combate e por isso deve ser lido por todos aqueles que defendem uma educação pública, gratuita, laica e que contemple todas as dimensões da vida humana.

\section{Referência}

SAVIANI, Dermeval. Escola e democracia, 43. ed. Campinas: Autores Associados, (2018). 